\title{
PENGARUH EC SAAT PEMBIBITAN TERHADAP HASIL SAWI (Brassica rapa L.) METODE HIDROPONIK SISTEM APUNG
}

\author{
Imam Ifanto dan Suprihati \\ Program Studi Agroteknologi \\ Fakultas Pertanian dan Bisnis, Universitas Kristen Satya Wacana \\ Jalan Diponegoro No. 52-60 Salatiga - Indonesia 50711 \\ email:imam.ifanto07@gmail.com
}

\begin{abstract}
ABSTRAK
Media tanam hidroponik yang tidak mengandung unsur hara dan pemberian nutrisi dengan EC (Electrical Conductivity) yang kurang tepat saat pembibitan mengakibatkan pertumbuhan bibit menjadi lambat, sehingga hasil sawi menjadi kurang maksimal. Penelitian ini untuk menentukan EC saat pembibitan yang memberikan hasil sawi terbaik, serta mengetahui EC saat pembibitan yang menghasilkan sawi tertinggi. Penelitian ini dilaksanakan di Desa Candirejo, Kecamatan Ungaran Barat, Kabupaten Semarang pada bulan Juli hingga Agustus 2018. Rancangan percobaan yang digunakan adalah Rancangan Acak Kelompok dengan 7 perlakuan yaitu (EC $0 \mathrm{mS}), \quad(E C$ 0,4 mS), (EC 0,8 $\mathrm{mS}),(E C 1,2 \mathrm{mS}),(E C 1,6 \mathrm{mS}),(E C 2,0 \mathrm{mS})$, dan $(E C 2,4 \mathrm{mS})$ dan 4 kali ulangan. Parameter pengamatan meliputi tinggi, jumlah daun, luas daun, diameter bonggol, panjang akar, bobot segar atas, dan bobot kering atas. Hasil pengamatan dianalisis menggunakan sidik ragam (uji F 5\%). Untuk mengetahui perbedaan antar perlakuan digunakan uji DMRT dengan selang kepercayaan 5\%. Hasil penelitian menunjukan EC 1,74 mS sampai 2,29 mS menghasilkan sawi terbaik dengan tinggi 30,10 $\mathrm{cm}$, jumlah daun 21,5 helai, luas daun 2270,66 $\mathrm{cm}^{2}$, dan diameter bonggol 8,63 cm. EC 2,4 mS menghasilkan sawi tertinggi dengan bobot 322,91 gram.
\end{abstract}

Kata kunci : EC, Pembibitan, Sawi, Hidroponik

\section{PENDAHULUAN}

Sawi (Brassica rapa L.) merupakan salah satu komoditas pertanian yang dapat dibudidayakan secara konvensional maupun secara hidroponik. Dalam budidaya tanaman secara hidroponik terdapat dua tahapan yaitu tahap pembibitan dan tahap produksi. Pembibitan merupakan suatu proses penanaman bibit dari benih hingga siap pindah tanam. Selama pembibitan, benih akan berimbibisi selama 3 hari. Setelah itu benih muncul tunas dan membentuk perkecambahan yang berlangsung selama 7 hari. Bibit yang siap pindah tanam adalah bibit yang sudah berumur 20 hari setelah semai (Herwibowo dan Budiana, 2016).

Hidroponik sistem apung merupakan metode budidaya tanaman dengan cara menanamkan tanaman pada lubang stayrofoam yang mengapung diatas permukaan air nutrisi dalam 
sebuah bak atau kolam sehingga air terendam dalam air nutrisi. Pada sistem ini nutrisi tidak dialirkan atau disirkulasikan melainkan dibiarkan begitu saja. Untuk menambah oksigen di dalam nutrisi maka ditambahkan aerator.

Media tanam yang sering digunakan dalam budidaya tanaman secara hidroponik adalah rockwool. Rockwool merupakan media tanam yang tidak mengandung unsur hara, dan hanya berperan sebagai penopang atau penyangga tanaman. Untuk mendapatkan unsur hara maka tanaman harus diberikan nutrisi dalam bentuk larutan (Sarawa, 2011). Sementara jika media tidak mengandung ketersediaan hara maka tanaman tidak mendapatkan hara untuk proses fisiologis, sehingga dapat menyebabkan pertumbuhan tanaman menjadi terhambat. Bibit yang tidak segera diberi nutrisi pertumbuhannya akan menjadi tidak maksimal, sehingga dapat mempengaruhi produksi (Mas'ud, 2009). Kurang maksimalnya pertumbuhan sawi pada tahap pembibitan juga disebabkan oleh pemberian nutrisi yang ECnya terlalu rendah. Pemberian nutrisi dengan EC yang yang terlalu rendah pada pembibitan seperti dibawah 1,0 $\mathrm{mS}$ dapat menyebabkan tanaman tidak dapat tumbuh dengan pesat (Pratiwi dkk., 2015; Subandi dkk., 2015; Saroh 2016).
Sedangkan jika nilai EC melebihi ambang batas seperti 3,0 mS dapat membuat tanaman menjadi rusak, seperti terbakarnya daun tanaman yang diawali dengan daun menjadi coklat yang perlahan mengering dan hangus (Sutiyoso, 2003).

Nilai EC yang dapat diaplikasikan pada tahap pembibitan yaitu berkisar 1,0 - 1,2 mS. Sedangkan pada tahap medium sampai tahap pembesaran nilai EC yang dapat diterapkan adalah 1,5 - 2,0 mS. Pemberian nutrisi saat pembibitan dengan EC yang tepat diharapkan dapat mengurangi penggunaan nutrisi yang berlebih pada tahap produksi. Budidaya tanaman dengan memperhatikan umur, nilai EC yang cukup dan berimbang bagi tanaman dapat mempengaruhi pertumbuhan seperti tinggi tanaman (Pratiwi dkk., 2015; Suryani, 2015; Binaraesa dkk., 2016).

Pada penelitian sebelumnya mengenai performa bibit sawi pakcoy pada berbagai nilai EC dengan metode hidroponik menunjukan bahwa EC saat pembibitan berpengaruh sangat nyata terhadap tinggi, jumlah daun, luas daun, dan bobot bibit. EC 1,74 $\mathrm{mS}$ sampai 2,33 mS menghasilkan performa bibit dengan maksimal yang meliputi tinggi, jumlah daun, luas daun, dan bobot bibit sawi pakcoy (Ifanto dan Suprihati, 2018). Dari penelitian tersebut belum diketahui pengaruh EC saat pembibitan 
terhadap hasil sawi. Oleh karena itu, perlu dilakukan penelitian mengenai pengaruh EC saat pembibitan terhadap hasil sawi dengan hidroponik sistem apung.

Tujuan penelitian ini adalah untuk menentukan EC saat pembibitan yang memberikan hasil sawi terbaik, serta mengetahui EC saat pembibitan yang menghasilkan sawi tertinggi. Manfaat dari penelitian ini untuk memberikan informasi mengenai pemberian EC saat pembibitan yang tepat agar dapat menghasilkan sawi terbaik.

\section{METODE PENELITIAN}

Penelitian dilakukan pada bulan Juli hingga Agustus 2018 di Desa Candirejo Kecamatan Ungaran Barat, Kabupaten Semarang dengan ketinggian tempat \pm 400 meter di atas permukaan laut. Bahan yang digunakan dalam penelitian ini antara lain, benih sawi pakcoy varietas Diana, air, rockwool, dan nutrisi hidroponik (AB mix). Sedangkan untuk alat yang digunakan adalah tds dan ec meter, $\mathrm{pH}$ meter, gelas ukur, ember, baki semai, penggaris, alat tulis, timbangan, thermohigrometer, dan pinset.

Penelitian ini menggunakan Rancangan Acak Kelompok (RAK) faktor tunggal dengan perlakuan berbagai taraf nilai EC saat pembibitan yang diujikan meliputi $0 \mathrm{mS}$; 0,4
$\mathrm{mS} ; 0,8 \mathrm{mS} ; 1,2 \mathrm{mS} ; 1,6 \mathrm{mS} ; 2,0 \mathrm{mS} ; 2,4 \mathrm{mS}$. Tiap perlakuan tersebut diulang sebanyak 4 kali sehingga didapatkan 28 satuan percobaan.

Parameter yang diamati meliputi tinggi tanaman, jumlah daun, luas daun, diameter bonggol, panjang akar, bobot segar, dan bobot kering. Hasil pengamatan dianalisis menggunakan metode sudik ragam (Uji F $5 \%$ ). Untuk mengetahui perbedaan antar perlakuan digunakan uji Duncan's Multiple Range Test (DMRT) dengan selang kepercayaan 5\%. Untuk mengetahui keeratan dan bentuk hubungan antar perlakuan digunakan uji korelasi dan regresi.

\section{HASIL DAN PEMBAHASAN}

Rata-rata suhu minimum ruang untuk pembibitan dan produksi berkisar antara 15-21 ${ }^{\circ} \mathrm{C}$, dan suhu maksimum berkisar $36-43{ }^{\circ} \mathrm{C}$. Kelembaban dalam greenhouse berkisar antara 45-55\%. Tingginnya suhu di dalam greenhouse disebabkan oleh struktur greenhouse yang beratap rendah dan tertutup sehingga menyebabkan pergerakan udara dengan lingkungan di luar sangat kecil. Sedangkan untuk kelembaban yang rendah terjadi karena suhu udara yang tinggi di dalam greenhouse yang membuat air pada baki dan kolam mengalami penguapan yang tinggi sehingga kelembaban dalam greenhouse menjadi rendah. 
Tabel 2. Pengaruh EC saat Pembibitan terhadap Tinggi (cm), Jumlah Daun (helai), Luas Daun $\left(\mathrm{cm}^{2}\right)$, Diameter Bonggol $(\mathrm{cm})$

\begin{tabular}{cccccccc}
\hline EC & $\begin{array}{c}\text { Tinggi } \\
(\mathrm{cm})\end{array}$ & $\begin{array}{c}\text { Jumlah Daun } \\
(\text { helai })\end{array}$ & $\begin{array}{c}\text { Luas Daun } \\
\left(\mathrm{cm}^{2}\right)\end{array}$ & $\begin{array}{c}\text { Diameter Bonggol } \\
(\mathrm{cm})\end{array}$ \\
\hline $0 \mathrm{mS}$ & 23,47 & $\mathrm{~d}$ & $13,8 \mathrm{~d}$ & 959,38 & $\mathrm{~d}$ & 6,84 & $\mathrm{c}$ \\
$0,4 \mathrm{mS}$ & $27,52 \mathrm{c}$ & $18,6 \mathrm{c}$ & 1626,05 & $\mathrm{c}$ & 8,16 & $\mathrm{~b}$ \\
$0,8 \mathrm{mS}$ & $28,62 \mathrm{~b}$ & $18,7 \mathrm{c}$ & 1773,96 & $\mathrm{~b}$ & 8,21 & $\mathrm{~b}$ \\
$1,2 \mathrm{mS}$ & $29,37 \mathrm{ab}$ & $19,3 \mathrm{bc}$ & 1979,69 & $\mathrm{~b}$ & 8,44 & $\mathrm{a}$ \\
$1,6 \mathrm{mS}$ & $29,43 \mathrm{ab}$ & $19,8 \mathrm{~b}$ & 2083,34 & $\mathrm{a}$ & 8,56 & $\mathrm{a}$ \\
$2,0 \mathrm{mS}$ & $29,57 \mathrm{ab}$ & $21,3 \mathrm{a}$ & $2181,25 \mathrm{a}$ & 8,62 & $\mathrm{a}$ \\
$2,4 \mathrm{mS}$ & $30,10 \mathrm{a}$ & $21,5 \mathrm{a}$ & $2270,66 \mathrm{a}$ & 8,63 & $\mathrm{a}$ \\
\hline
\end{tabular}

Ket : Angka yang diikuti oleh notasi huruf yang sama menunjukan tidak berbeda nyata antar perlakuan pada uji DMRT $5 \%$

Bibit dengan pertumbuhan dan perkembangan yang maksimal akan menghasilkan pertumbuhan dan produksi yang maksimal secara kuantitas dan kualitas. Oleh karena itu untuk memaksimalkan hasil sawi maka salah satunya dengan memberikan nutrisi di tahap pembibitan dengan EC yang tepat.

\section{Pengaruh EC saat Pembibitan terhadap}

\section{Hasil Sawi}

Tabel 1. Rekapitulasi Hasil Sidik Ragam Pengaruh EC saat Pembibitan Terhadap Hasil Sawi

\begin{tabular}{llc}
\hline \multicolumn{1}{c}{ Peubah } & Satuan & F Hitung \\
\hline Tinggi & $\mathrm{cm}$ & $57,25^{* *}$ \\
Jumlah Daun & helai & $84,65^{* *}$ \\
Luas Daun & $\mathrm{cm}^{2}$ & $74,63^{* *}$ \\
Diameter Bonggol & $\mathrm{cm}$ & $114,35^{* *}$ \\
Panjang Akar & $\mathrm{cm}$ & $101,07^{* *}$ \\
Bobot Segar Atas & $\mathrm{g}$ & $102,65^{* *}$ \\
Bobot Kering Atas & $\mathrm{g}$ & $45,75^{* *}$ \\
\hline \multicolumn{2}{l}{ Ket : ** = berpengaruh sangat nyata uji F } & taraf 1\% \\
\multicolumn{2}{l}{$*$ berpengaruh nyata uji F 5\% } \\
\multicolumn{2}{l}{ tn = tidak berpengaruh nyata }
\end{tabular}

Berdasarkan hasil sidik ragam (uji $\mathrm{F}=5 \%$ ) (tabel 1) pemberian EC saat pembibitan berpengaruh sangat nyata terhadap tinggi, jumlah daun, luas daun, diameter bonggol, panjang akar, bobot segar, dan bobot kering tanaman sawi.

\section{Tinggi, Jumlah Daun, Luas Daun dan}

\section{Diameter Bonggol Tanaman Sawi}

Pada tabel 2 perlakuan EC $2,4 \mathrm{mS}$ menunjukan hasil yang tidak berbeda nyata dengan EC 1,6 $\mathrm{mS}$ dan 2,0 $\mathrm{mS}$ dengan memberikan hasil tertinggi pada parameter tinggi, jumlah daun, luas daun, dan diameter bonggol tanaman sawi. Hal ini dikarenakan ketersediaan dan serapan unsur hara yang tinggi oleh tanaman, sehingga tanaman dapat memacu pertumbuhan vegetatifnya dengan baik. EC yang tinggi dapat mempercepat pertumbuhan terutama pada tinggi tanaman, seiring dengan 
bertambahnya umur tanaman (Manullang dkk., 2014; Subandi dkk., 2015).

Hubungan antara EC saat pembibitan dengan parameter pertumbuhan dapat dilihat pada tabel 3. Terbentuk hubungan yang bersifat kudaratik pada parameter tinggi, jumlah daun, luas daun, dan diameter bonggol tanaman sawi. Dimana meningkatnya EC akan diikuti dengan meningkatnya tinggi, jumlah daun, luas daun, dan diameter bonggol tanaman sawi hingga mencapai titik puncak dan kemudian menurun seiring dengan peningkatan EC selanjutnya.

Berdasarkan persamaan regresei yang ada pada tabel 3 maka didapatkan nilai EC maksimal saat pembibitan untuk mendapatkan pertumbuhan dengan hasil yang maksimum. Tinggi tanaman maksimum dapat dicapai pada EC 1,82 mS, jumlah daun maksimum pada EC 2,29 mS, luas daun maksimum pada EC 2,16, dan diameter bonggol maksimum dapat dicapai pada EC $1,79 \mathrm{mS}$.

Pada perlakuan EC 2,4 mS saat pembibitan dapat menghasilkan tinggi, jumlah daun, luas daun, dan diameter bonggol tanaman sawi terbaik dibanding perlakuan lainnya. Hal tersebut terjadi karena tingginya tanaman dalam menyerap hara nitrogen pada nutrisi yang digunakan tanaman untuk merangsang pertumbuhan secara keseluruhan (Rizal, 2017). Dalam hal ini nitrogen berfungsi sebagai pembentuk klorofil yang berperan penting dalam proses fotosintesis, juga sebagai pembentuk protein, lemak dan berbagai persenyewaan organik lainnya. Selian unsur N tanaman juga menyerap unsur $\mathrm{P}$ dan $\mathrm{K}$, yang berperan penting dalam pembelahan sel, pembesaran, perkembangan jaringan meristematik, dan berfungsi sebagai pengaktif dari sejumlah enzim yang penting untuk proses fotosintesis dan respirasi (Marginingsih dkk., 2018).

Sedangkan pada perlakuan EC $0 \mathrm{mS}$ dan 0,4 $\mathrm{mS}$ nyata memberikan hasil terendah pada seluruh parameter pertumbuhan. Hal ini

Tabel 3. Rekapitulasi Regresi EC saat Pembibitan dengan Parameter Pertumbuhan Sawi

\begin{tabular}{llcc}
\hline Parameter & Persamaan Regresi & $\mathrm{R}^{2}$ & $\begin{array}{c}\text { EC Maks } \\
(\mathrm{mS})\end{array}$ \\
\hline Tinggi & $\mathrm{y}=-1,770 \mathrm{x}^{2}+6,463 \mathrm{x}+24,22$ & 0,761 & 1,82 \\
Jumlah Daun & $\mathrm{y}=-1,213 \mathrm{x}^{2}+5,548 \mathrm{x}+14,87$ & 0,736 & 2,29 \\
Luas Daun & $\mathrm{y}=-248,5 \mathrm{x}^{2}+1074, \mathrm{x}+1066$ & 0,820 & 2,16 \\
Diameter Bonggol & $\mathrm{y}=-0,499 \mathrm{x}^{2}+1,793 \mathrm{x}+7,095$ & 0,676 & 1,79 \\
Panjang Akar & $\mathrm{y}=-4,342 \mathrm{x}^{2}+15,11 \mathrm{x}+35,10$ & 0,810 & 1,74 \\
Bobot Segar Atas & $\mathrm{y}=-50,17 \mathrm{x}^{2}+186,7 \mathrm{x}+152,9$ & 0,728 & 1,86 \\
Bobot Kering Atas & $\mathrm{y}=-2,360 \mathrm{x}^{2}+9,081 \mathrm{x}+7,193$ & 0,845 & 1,92 \\
\hline
\end{tabular}


disebabkan adanya kekurangan hara yang terlihat pada pertumbuhan batang dan daun saat di pembibitan. Kurangnya suplai hara ke organ bagian atas tanaman dikarenakan akar dalam keadaan terbatas dalam merespon maupun menyerap nutrisi. Sehingga pertumbuhan tanaman menjadi tidak maksimal. Kemudian EC yang rendah mengandung unsur hara seperti $\mathrm{N}$, $\mathrm{P}$, dan $\mathrm{K}$ yang rendah pula sehingga membuat proses fisiologi tanaman menjadi tidak maksimal yang menyebabkan proses pertumbuhan dan perkembangan menjadi lambat (Dermawati 2006; Subandi dkk., 2015).

Berdasarkan uji korelasi antar parameter pertumbuhan sawi (tabel 4) menunjukan keeratan hubungan antar parameter pertumbuhan tanaman sawi. Tinggi tanaman memiliki keeratan yang erat dengan parameter luas daun, jumlah daun, dan diameter bonggol dengan nilai $0,8437,0,8428$, dan 0,8057. Luas daun memiliki keeratan yang erat dengan parameter diameter, jumlah daun, dan tinggi tanaman dengan nilai 0,9227, 0,9193, dan 0,8437. Kemudian diameter bonggol berhubungan erat dengan luas daun, jumlah daun, dan tinggi tanaman dengan nilai 0,9227, 0,8416, dan 0,8057. Hal ini disebabkan karena daun berfungsi sebagai penghasil fotosintat, dimana semakin besar daun menghasilkan fotosintat maka pembentukan organ-organ vegetatif seperti tinggi tanaman, luas daun, dan diameter bongol tanaman akan semakin baik (Widodo dkk., 2017). Parameter jumlah daun berhubungan erat dengan parameter luas daun, tinggi tanaman, dan diameter bonggol dengan nilai $0,9193,0,8428$, dan 0,8416 . Hal ini disebabkan karena hasil fotosintat dari daun digunakan untuk mendukung perkembangan daun dan sebagian ditranslokasikan pada bagian tanaman lainnya seperti batang (Subandi dkk., 2015).

\section{Bobot Segar Brangkasan Atas Tanaman}

\section{Sawi}

Berdasarkan hasil uji DMRT 5\% (tabel 5)

Tabel 4. Rekapitulasi Korelasi Antar Parameter Pertumbuhan Sawi

\begin{tabular}{llllllll}
\hline & Tinggi & $\begin{array}{l}\text { Jumlah } \\
\text { Daun }\end{array}$ & $\begin{array}{l}\text { Luas } \\
\text { Daun }\end{array}$ & $\begin{array}{l}\text { Diameter } \\
\text { Bonggol }\end{array}$ & $\begin{array}{l}\text { Panjang } \\
\text { Akar }\end{array}$ & $\begin{array}{l}\text { Bobot } \\
\text { Segar }\end{array}$ & $\begin{array}{l}\text { Bobot } \\
\text { Kering }\end{array}$ \\
\hline Tinggi & 1 & 0,8428 & 0,8437 & 0,8057 & 0,9123 & 0,8499 & 0,8639 \\
Jumlah Daun & 0,8428 & 1 & 0,9193 & 0,8416 & 0,8603 & 0,8891 & 0,9353 \\
Luas Daun & 0,8437 & 0,9193 & 1 & 0,9227 & 0,8819 & 0,9391 & 0,9296 \\
Diameter Bonggol & 0,8057 & 0,8416 & 0,9227 & 1 & 0,8356 & 0,9125 & 0,9123 \\
Panjang Akar & 0,9123 & 0,8603 & 0,8819 & 0,8356 & 1 & 0,8676 & 0,9119 \\
Bobot Segar Atas & 0,8499 & 0,8891 & 0,9391 & 0,9125 & 0,8676 & 1 & 0,9616 \\
Bobot Kering Atas & 0,8639 & 0,9353 & 0,9296 & 0,9123 & 0,9119 & 0,9616 & 1 \\
\hline
\end{tabular}


pengaruh EC saat pembibitan memperlihatkan perlakuan EC 2,4 mS tidak berbeda nyata dengan 1,6 mS dan 2,0 mS yang memberikan hasil tertinggi pada parameter bobot segar atas. Hasil tertinggi pada perlakuan tersebut disebabkan karena banyak hara yang mampu diserap oleh tanaman sehingga tanaman tumbuh dan berkembang secara maksimal sesuai dengan fase pertumbuhannya. Tanaman dengan pertumbuhan dan perkembangan yang maksimal akan menghasilkan panen yang maksimal secara kuantitas dan kualitas. Tingginya bobot segar diindikasi adanya serapan hara $\mathrm{N}$ yang tinggi (Bhaskoro dkk., 2015).

Tabel 5. Pengaruh EC saat Pembibitan terhadap Bobot Segar Atas (g)

\begin{tabular}{ccc}
\hline EC & $\begin{array}{c}\text { Panjang } \\
\text { Akar (cm) }\end{array}$ & $\begin{array}{c}\text { Bobot } \\
\text { Segar Atas } \\
(\mathrm{g})\end{array}$ \\
\hline $0 \mathrm{mS}$ & $33,45 \mathrm{~d}$ & $132,58 \mathrm{~d}$ \\
$0,4 \mathrm{mS}$ & $42,63 \mathrm{c}$ & $244,70 \mathrm{c}$ \\
$0,8 \mathrm{mS}$ & $45,42 \mathrm{~b}$ & $289,09 \mathrm{~b}$ \\
$1,2 \mathrm{mS}$ & $46,52 \mathrm{ab}$ & $289,76 \mathrm{~b}$ \\
$1,6 \mathrm{mS}$ & $46,74 \mathrm{a}$ & $308,51 \mathrm{ab}$ \\
$2,0 \mathrm{mS}$ & $47,37 \mathrm{a}$ & $320,85 \mathrm{a}$ \\
$2,4 \mathrm{mS}$ & $47,39 \mathrm{a}$ & $322,91 \mathrm{a}$ \\
\hline
\end{tabular}

Ket : Angka yang diikuti oleh notasi huruf yang sama menunjukan tidak berbeda nyata antar perlakuan pada uji DMRT 5\%

Sedangkan pada perlakuan EC $0 \mathrm{mS}$ dan 0,4 $\mathrm{mS}$ menunjukan hasil terendah pada parameter tersebut. Hal ini dikarenakan pada EC $0 \mathrm{mS}$ dan $0,4 \mathrm{mS}$ memiliki panjang akar yang lebih pendek dibanding dengan perlakuan yang lain.
Panjangnya akar tanaman menunjukan bahwa akar lebih aktif dalam menyerap unsur hara dalam nutrisi yang telah disediakan. Akar tanaman yang panjang dan banyak terjadi karena tingginya serapan hara oleh akar. Dalam hal ini akar berfungsi sebagai penyerap unsur hara, dimana semakin panjang dan banyak akar, membuat unsur hara yang dieserap akan semakin banyak, sehingga kebutuhan unsur hara yang dibutuhkan oleh tanaman akan semakin terpenuhi (Oktarina dan Purwanto, 2009). Pertumbuhan tanaman yang baik juga dipengaruhi oleh proses respirasi akar yang lancar sehingga menghasilkan tanaman banyak energi untuk pembentukan komponen pertumbuhan tanaman seperti tinggi, jumlah daun, luas daun (Pratiwi dkk., 2015).

Hubungan antara EC saat pembibitan dengan bobot segar tanaman sawi dapat dilihat pada gambar 1. Terbentuk hubungan yang bersifat kuadratik, dimana meningkatnya EC pembibitan akan diikuti dengan meningkatnya bobot segar atas tanaman sawi hingga mencapai titik puncak dan kemudian menurun seiring dengan peningkatan EC selanjutnya. Sehingga bobot segar sawi maksimum dapat dicapai pada EC $1,86 \mathrm{mS}$. 


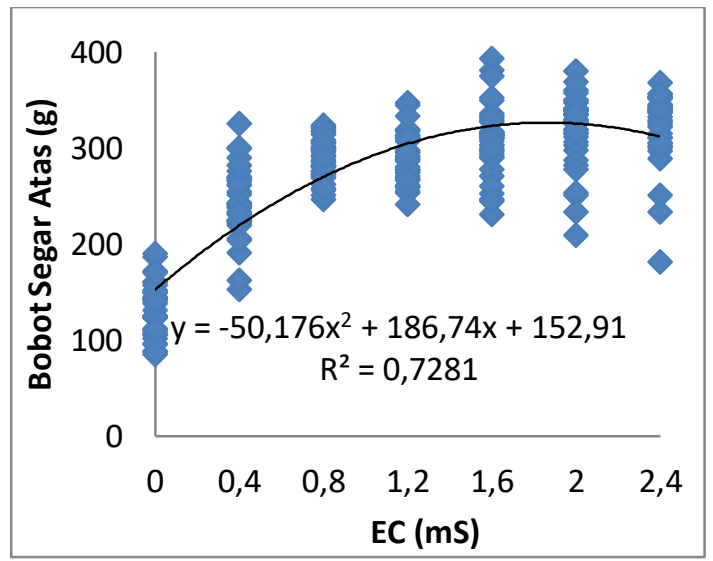

Gambar 1. Hubungan EC saat pembibitan dengan bobot segar atas tanaman sawi

Parameter bobot segar atas memiliki keeratan yang erat dengan parameter luas daun, diameter bonggol, Jumlah daun, dan tinggi tanaman dengan hasil 0,9391, 0,9125, 0,8891, dan 0,8499. Hal ini dikarenakan parameter pertumbuhan seperti luas daun, diameter bonggol, Jumlah daun, dan tinggi tanaman merupakan organ bagian atas. Hal ini didukung dengan persamaan linier berganda $\mathrm{y}=1,8946$ $\mathrm{X}_{1}+4,3226 \mathrm{X}_{2}+53,5936 \mathrm{X}_{3}+0,0408 \mathrm{X}_{4}-$ $377,775\left(R^{2}=0,9384, n=56, y=\operatorname{BSA}(g), X_{1}=\right.$ tinggi tanaman (cm), $\mathrm{X}_{2}=$ jumlah daun (helai), $\mathrm{X}_{3}=\operatorname{diameter}(\mathrm{cm}), \mathrm{X}_{4}=$ luas daun $\left.\left(\mathrm{cm}^{2}\right)\right)$.

Meningkatnya pertumbuhan tanaman seperti tinggi, diameter, jumlah daun, dan luas daun akan menghasilkan bobot segar atas yang lebih baik. hal ini juga sejalan dengan penelitian Perwitasari dkk. (2012) yang menyatakan bahwa bobot segar tanaman akan semakin meningkat jika parameter pertumbuhan seperti jumlah daun, luas daun, dan diameter bonggol mengalami peningkatan dan juga menghasilkan parameter pertumbuhan yang terbaik. Parameter pertumbuhan bagian atas tersebut tidak lepas dari peran akar. Dimana pertumbuhan bagian atas sangat ditunjang dengan keaadan dan kondisi perakaran. Pertumbuhan dan perkembangan akar yang baik berpengaruh posistif terhadap kemampuan tanaman dalam menyerap unsur hara dan air umtuk membuat pertumbuhan tanaman menjadi maksimal (Rohmaniyah dkk., 2015).

Berdasarkan tabel 5 maka dapat disarankan untuk menggunakan EC saat pembibitan dengan EC 1,6 mS. Hal ini dikarenakan hasil dari uji DMRT dengan selang kepercayaan 5\% perlakuan EC 1,6 mS mampu menghasilkan bobot segar atas tanaman sawi sebasar 308,51 gram dimana hasil tersebut tidak berbeda nyata dengan perlakuan EC 2,0 mS dan 2,4 mS dengan hasil 320,85 gram dan 322,91 gram.

\section{Bobot Kering Brangkasan Atas Tanaman Sawi}

Berat kering atas tanaman merupakan ukuran biomasa yang dibentuk selama pertumbuhan dan merupakan indikator pertumbuhan tanaman yang sesungguhnya. Perlakuan EC yang diberikan pada saat tahap pembibitan memberikan pengaruh yang nyata terhadap bobot kering tanaman. Kemudian dari hasil bobot kering atas (tabel 6) perlakuan EC 
2,4 mS, 2,0 mS, dan 1,6 mS nyata memberikan hasil tertinggi pada parameter tersebut.

Tabel 6. Pengaruh EC saat Pembibitan terhadap Bobot Kering Atas (g) Tanaman Sawi

\begin{tabular}{cc}
\hline EC & $\begin{array}{c}\text { Bobot Kering } \\
\text { Atas }(\mathrm{g})\end{array}$ \\
\hline $0 \mathrm{mS}$ & $6,23 \mathrm{~d}$ \\
$0,4 \mathrm{mS}$ & $11,88 \mathrm{c}$ \\
$0,8 \mathrm{mS}$ & $13,24 \mathrm{~b}$ \\
$1,2 \mathrm{mS}$ & $13,71 \mathrm{~b}$ \\
$1,6 \mathrm{mS}$ & $15,46 \mathrm{a}$ \\
$2,0 \mathrm{mS}$ & $15,72 \mathrm{a}$ \\
$2,4 \mathrm{mS}$ & $15,77 \mathrm{a}$ \\
\hline
\end{tabular}

Ket : Angka yang diikuti oleh notasi huruf yang sama menunjukan tidak berbeda nyata antar perlakuan pada uji DMRT 5\%

Tingginya bobot kering didukung oleh komponen pertumbuhan yang menghasilkan pertumbuhan dengan maksimal atau terbaik mulai dari tinggi tanaman, jumlah daun, diameter bonggol, dan luas daun. Selain itu proses metabolisme seperti fotosintesis yang berlangsung cepat dan hasil dari fotosintesis dapat disimpan di organ-organ tanaman dengan maksimal, terjadi penimbunan hasil fotosintesis yang lebih banyak sehingga berat kering tanamanpun akan meningkat. Semakin tinggi hasil bobot kering suatu tanaman menunjukkan bahwa semakin banyak pula unsur hara yang ditranslokasikan kebagian tanaman seperti batang dan daun (Istarofah dan Salamah, 2017).

Hubungan antara EC saat pembibitan dengan bobot kering tanaman sawi dapat dilihat pada Gambar 2. Terbentuk hubungan yang bersifat kuadratik, dimana meningkatnya EC saat pembibitan akan diikuti dengan meningkatnya bobot kering atas tanaman sawi hingga mencapai titik puncak dan kemudian menurun seiring dengan peningkatan EC selanjutnya. Sehingga bobot kering atas maksimum dapat dicapai pada EC 1,92 mS.

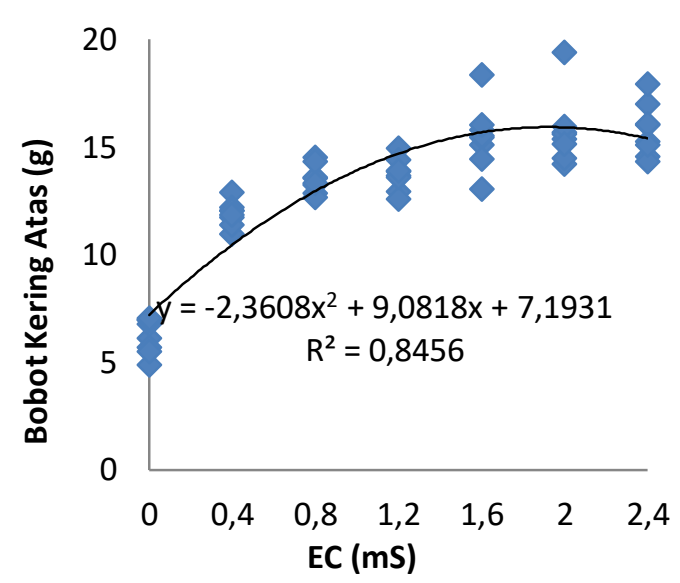

Gambar 2. Hubungan EC saat pembibitan dengan bobot kering atas tanaman sawi

Pada tabel 4 parameter bobot kering memiliki keeratan yang erat dengan parameter tinggi, jumlah daun, luas daun, dan diameter bonggol tanaman sawi dengan nilai 0,8639, 0,9353, 0,9296, dan 0,9123. Dimana semakin tinggi hasil pertumbuhan tinggi tanaman, jumlah daun, luas daun, dan diameter bonggol maka bobot kering atas akan semakin meningkat.

\section{KESIMPULAN}

1. EC 1,74 mS sampai 2,29 menghasilkan sawi terbaik dengan tinggi $30,10 \mathrm{~cm}$, 
jumlah daun 21,5 helai, luas daun 2270,66 $\mathrm{cm}^{2}$, dan diameter bonggol $8,63 \mathrm{~cm}$.

2. EC $2,4 \mathrm{mS}$ menghasilkan bobot segar brangkasan atas sawi paling berat : 322,91 gram.

\section{DAFTAR PUSTAKA}

Binaraesa, N.N.P.C., S.M. Sutan, dan A.M. Ahmad. 2016. Nilai EC (Electrical Conductivity) berdasarkan umur tanaman selada daun hijau (Lactuca sativa L.) dengan sistem hidroponik nft (nutrient film technique). Jurnal Keteknikan Pertanian Tropis dan Biosistem. 4 (1): 6574.

Bhaskoro, A.W., K. Novalia, dan Syekhfani. 2015. Efisiensi pemupukan nitrogen tanaman sawi pada inceptisol melalui aplikasi zeolit alam. Jurnal Tanah dan Sumberdaya Lahan. 2 (2): 219-226.

Dernawati. 2006. Substitusi Hara Mineral Organik terhadap Inorganik terhadap Produksi Tanaman Pakchoy (Brassica rapa L.). Tesis.Bogor: Fakultas MIPA Institut Pertanian Bogor. $111 \mathrm{hlm}$.

Herwibowo, K dan N.S. Budiana. 2016. Hidroponik Sayuran Untuk Hobi dan Bisnis. Jakarta: Penebar Swadaya. $132 \mathrm{hlm}$

Ifanto, I dan Suprihati. 2018. Performa bibit sawi pakcoy (Brassica rapa L.) pada berbagai ec (electrical conductivity) dengan metode hidroponik. Salatiga: Prosiding Konser Karya Ilmiah Tingkat Nasional Tahun 2018.

Istarofah dan Z. Salamah. 2017. Pertumbuhan tanaman sawi hijau (Brassica rapa L.) dengan pemberian kompos berbahan dasar daun paitan (Thitinia diversifolia). Jurnal Bio-site. 3 (3): 39-46.

Manullang, G.S., R. Abdul, dan A. Puji. 2014. Pengaruh jenis dan konsentrasi pupuk organik cair terhadap pertumbuhan dan hasil tanaman sawi (Brassica juncea L.) varietas tosakan. Jurnal Agrifor. 8 (1): 1412-6885.

Marginingsih, R.S., A.S. Nugroho, dan M. A. Dzakiy. 2018. Pengaruh substansi pupuk organic cair pada nutrisi ab mix terhadap pertumbuhan caisim (Brassica juncea L.) pada hidroponik drip irrigation system. Jurnal Biologi dan Pembelajarannya. 5 (1): 44-51.

Mas`ud, H. 2009. Sistem hidroponik dengan nutrisi dan media tanam berbeda terhadap pertumbuhan dan hasil selada. Jurnal Media Litbang Sulteng. 2 (2): 131-136.

Oktarina dan E.B. Purwanto. 2009. Responsibilitas pertumbuhan dan hasil selada (Lactuca sativa) secara hidroponik terhadap konsentrasi dan frekuensi larutan nutrisi. Jurnal Agritop Ilmu-Ilmu Pertanian. 6 (2): 125-132.

Perwitasari, B., M. Tripatmasari, dan W. Wasonowati. 2012. Pengaruh media tanam dan nutrisi terhadap pertumbuhan dan hasil tanaman pakchoi dengan sistem hidroponik. Jurnal Agrivor. 5 (1):14-25.

Pratiwi, R.P., M. Subandi, dan M. Eri. 2015. Pengaruh tingkat EC (Electrical

Conductivity) terhadp pertumbuhan tanaman sawi (Brassica juncea L.) pada sistem instalasi aeoroponik vertikal. Jurnal Agro. 2 (1): 50-55.

Rizal, S. 2017. Pengaruh nutrisi yang diberikan terhadap pertumbuhan tanaman sawi pakcoy (Brassica rapa L.) yang ditanam secara hidroponik. Jurnal Sainmatika. 14 (1): 38-44.

Rohmaniyah, L.K., D. Indradewa, dan E.T.S. Putra. 2015. Tanggapan tanaman kangkung (Ipomea reptans Poir), bayam (Amarantus tricolor L), dan selada (Lactuca sativa L.) terhadap pengayaan kalsium secara hidroponik. Jurnal Vegetalika. 4 (2): 63-78. 
Sarawa. 2011. Perkecambahan dan pertumbuhan tanaman sawi (Brassica juncea L.) yang diberi pupuk cair nutriflora dengan sistem hidroponik. Jurnal Agroteknos. 1 (2): 82-88.

Subandi, M., N.P. Salam, dan B. Frasetya. 2015. Pengaruh berbagai nilai ec (electrical conductivity) terhadap pertumbuhan dan hasil bayam (Amaranthus sp.) pada hidroponik sistem rakit apung (floating hidroponics system). Jurnal Agroekoteknologi. 9 (2): 136-152.

Suryani, R. 2015. Hidroponik Budidaya Tanaman Tanpa Tanah. Yogyakarta: Arcitra. 200 hlm.

Sutiyoso, Y. 2003. Meramu Pupuk Hidroponik. Jakarta: Penebar Swadaya. $122 \mathrm{hlm}$.

Widodo, S., Suoriyono, dan T. Irawatai. 2017. Pengaruh umur bibit dan umur panen terhadap pertumbuhan dan produksi hidroponik nft tanaman selada (Lactuca sativa L.) varietas grand rapids. Jurnal Hijau Cendekia. 2 (2): 21-26. 